\title{
dossier $\mid$ BRAZIL, BELGIUM, AND FRANCE: \\ avenues for comparison work
}

Copyright (๑) 2019 SBPjor / Associação Brasileira de Pesquisadores em Jornalismo

\section{FLORENCE LE CAM}

ReSIC-LaPIJ, Université Libre de Bruxelles / Arènes, Université de Rennes I, Bruxelas e Rennes - Belgium and France

ORCID: 00000-0002-5550-5167

\begin{abstract}
This paper proposes that conducting binational and international comparisons in journalism studies could be a fundamental element towards stimulating collaborative relations between Belgian, Brazilian and French universities. There are three major points developed in this paper: the question of comparability in international studies; the dynamics of the theoretical framework and the methodological choices; and the creation of binational or trinational research groups that, when working together, could in fact enrich the national and comparative perspectives of journalism study. Lastly, this paper reinforces the political and scientific importance of opening up research and research practices on a national level.
\end{abstract}

Key Words: International comparison. Collective research. France. Belgium. Brazil.

\section{BRASIL, BÉLGICA, FRANÇA: pistas para trabalhar a comparação}

RESUMO - Este artigo propõe considerar que conduzir comparações internacionais binacionais nos estudos de jornalismo poderia se constituir em fator fundamental de ativação das relações de cooperação entre universidades belgas, brasileiras e francesas. Nesse sentido, este texto desenvolve três pontos: o primeiro retoma a questão da comparabilidade nos estudos internacionais; o segundo detalha as dinâmicas ligadas ao enquadramento teórico e às escolhas metodológicas e propõe a criação de binômios de pesquisa bi ou trinacionais que, trabalhando de forma concertada, poderiam de fato enriquecer as perspectivas nacionais e comparativas de estudo em jornalismo. Finalmente, este texto reforça a importância política e científica da abertura nacional da pesquisa e das práticas dos pesquisadores.

Palavras-chave: Comparação Internacional. Pesquisa Coletiva. França. Bélgica. Brasil. 


\section{BRASIL, BÉLGICA, FRANCIA: pistas para trabajar la comparación}

RESUMEN - Este artículo propone considerar que realizar comparaciones internacionales binacionales en estudios de periodismo podría ser un factor fundamental para activar las relaciones de cooperación entre las universidades belgas, brasileñas y francesas. En este sentido, este texto desarrolla tres puntos: el primero aborda la cuestión de la comparabilidad en estudios internacionales; el segundo detalla la dinámica vinculada al marco teórico y las escuelas metodológicas y propone la creación de binomios de investigación bi o trinacionales que, trabajando en conjunto, podrían enriquecer las perspectivas nacionales y comparativas del estudio del periodismo. Finalmente, este texto refuerza la importancia política y científica de la apertura nacional de la investigación y las prácticas de los investigadores.

Palabras clave: Comparación internacional. Investigación colectiva. Francia. Bélgica. Brasil.

\section{Introduction}

The first colloquium entitled 1st Brazil-France-Francophone Belgium Journalism Research - The Sociocultural Frontiers of Journalism in Brazil and in Francophone space was held in São Paulo in November 2018, and was the fruit of dozens of years of exchanges, circulation, travel and meetings. The history of these collaborations has already been presented by Adghirni and Pereira (2011) in an article on the REJ Journalism Studies Network / Réseau d'études sur le journalisme), a collaborative network of Francophone and Francophile researchers from Germany, Belgium, Brazil, Canada, France and Mexico. This network was made possible through the Mejor Colloquium, created in 2011 by Fábio Pereira and Zélia Adghirni, on the structural changes of journalism (Moura et al., 2015; Le Cam \& Ruellan, 2014). The Colloquium united Lusophone and Francophone researchers in discussions on common themes. These themes were decided on every two years (Mejor 2013; Mejor 2015). Two methodological dynamics fundamental to journalism research were also used in specific studies on interviews (Broustau et al., 2012), on the norms of researchers (Le Cam \& Pereira, 2016), and on comparison (Anciaux et al., 2017). These initiatives were a continuation of REJ 
activities but focused less on collaborations solely in French and more on debates between Lusophones and Francophones.

These international research exchanges also included efforts from Frisque (2016) in his presentation on how these relationships led to the creation of the journal Sur le journalisme (On journalism). This trilingual (or better yet, quadrilingual) magazine is edited by seven different editors from Belgium, Brazil, Canada and France, and supported by different laboratories and research center (ReSIC and LaPIJ in Belgium, Arènes in France), by funding agencies (FNRS in Belgium) by universities (Brasilia, Brussels, Paris, Quebec), and recently by the Brazilian Association of Journalism Researchers (SBPJor). The goal of this magazine is to provide a space for publications, for exchanges, and above all, for the circulation of articles written in each author's native language, with abstracts written in three or even four languages in an attempt to promote the international circulation of texts and ideas.

All of these experiments, undertaken since the late 1990s, have mostly contributed to meetings among researchers and developing collaborations between two or more researchers who wish to work within or outside these study networks. A new path began in 2013 during the 2nd Mejor Colloquium where discussions were held on international comparisons: conducting comparative research projects. Some researchers began to work together on projects (notably Le Cam \& Pereira, 2017a; 2015), and others began to collaborate together (such as Gilles Bastin from the Grenoble Institute of Political Studies and Jacques Mick from the Santa Catarina Federal University). These joint efforts led to collaborations between doctoral students from the Free University of Brussels (Belgium) and the University of Brasilia (Brazil), initiated in December, 2017. These collaborations involve two researchers from different nationalities mutually choosing an object of research and working, as a group, on a comparative problematization for it, and then conducting an empirical study and analysis. One of these groups has just published its primary research results in this issue of the Brazilian Journalism Research (see Arraes, Malcorps and Moraes). A second seminar for doctoral students is scheduled for November 2019, where the final research results will be presented.

This comparative path is beneficial towards structuring and encouraging cooperative relations between Brazilian, French and Belgian researchers (which could one day expand to include others). 
It has allowed us to exchange theoretical frameworks and similar thought processes on methods, to challenge our preconceptions, notions, and research habits, and also to work with and manage the routine languages of our research practices. Based on other reflective works by researchers on comparison in journalism studies (see Örnebring, 2012; or Hanitzsch, 2009), this text continues the exchanges begun a few years ago by Fábio Pereira from the University of Brasilia'. It also reflects on comparisons of three central elements common to comparative studies which will be discussed in the light of journalism studies: comparability and levels of comparison; the dynamics of theoretical framing and methodological choices; and lastly, the political and scientific importance of new national research and researcher practices.

\section{Comparability and levels of comparison in the three countries}

The histories of the three countries, including their economic, cultural, political and social contexts, are so distinct that they pose the obvious question of whether they are relevant, and also whether a comparison is feasible. How do you compare journalism in a country as large as Brazil, with 145,000 journalists in 2012 (Mick \& Lima, 2013), with a country like Belgium, where its entire population is smaller than the metropolitan region of São Paulo? Nevertheless, two avenues have been opened in recent years for comparative approaches: large quantitative surveys and simpler, qualitative research projects, which have more measured goals.

The first avenue is large quantitative surveys. Large teams work with intersecting themes: the profiles of journalists, the level of professionalization, the perception of the social role of journalists, etc. In these cases, the work of translating/interchanging the analysis categories or creating national variables is mainly performed by large transnational teams for the different research stages or by using statistical methods to make the research results visible and consistent. A prototypical example of this type of analysis in journalism studies is the Worlds of Journalism project, edited by Thomas Hanitzsch, who has just published the most recent edition (Hanitzsch et al., 2019). This major international study is described as follows: "Based on a landmark study that has collected data from more than 27,500 journalists in 67 countries, Worlds of Journalism 
offers a groundbreaking analysis of the different ways journalists perceive their duties, their relationship to society and government, and the nature and meaning of their work"2. The results present us with global differences or similarities, but also allow us to compare individual countries with each other. However, the questionnaire is similar for all countries and does not take into account certain national, cultural, political or economic specificities. Belgian, French and Brazilian teams participated in all the surveys.

The other avenue of comparison is one which was conducted specifically within the scope of this article and which Fábio Pereira has used in his works. We have tried to carry out a more micro approach, one based on journalists and their individual trajectories and careers, and their place within their country's society and history. The comparison approach was central to our research project as it allowed us to produce epistemological breakdowns of our personal realities, distancing ourselves from our presuppositions and arriving at a certain kind of "sociological disillusionment" (Mendras, 1995, p. 81), in the sense of separating oneself from his or her own ethnocentrism. We are looking to deconstruct the exceptional, denaturalize the national context, and integrate different levels of analysis. There are two elements which seem to us to be fundamental starting points: moving away from north-south positions in research and searching for a level of comparison that actually combines the individual ways of conceiving professional identity with the circulation of transnational discourse that may, in turn, shape these positions. Working in this way would allow us to refocus and, in some cases, to decentralize our research habits, offering an in-depth look at a national context different from those in our studies and, most importantly, to work with different levels of comparison. There are four possible levels which would help to initiate, and later elaborate on, comparative studies between France, Belgium and Brazil.

a) Studying the transnational circulation of ideas, the ways of doing things, and the imaginary in each of the countries. Guillaume Pinson (2016) has pioneered this kind of research with his works on the circulation of media imaginary: he analyzes how large circulations of newspapers and journalists have formed, from 1760 to 1936, from Paris to Brussels to Geneva, from Montreal to New Orleans, and up to New York, thus giving rise to the first francophone movement of media globalization. This is what could be considered 
the first point of comparison: to understand how circulation occurred between Brazil and France, between France and Belgium, and even between Belgium and Brazil. There are ways to produce newspapers, to frame news, to travel, and to have the north and south meet that can form the basis for various research projects. In this regard, we cite the work of Ailton Sobrinho, who studied the influence France had on 19th century Brazilian literary journalism (Sobrinho, 2018).

The second way of perceiving international circulations echoes the works of Hassenteufel (2005) and his idea of "transference". This idea is fundamental because it opens the door to a concept of "transnational" that is not only useful for comparison purposes, but also for studying a process, a conception, and ways of being and doing journalism. For example, it allows us to discover how the knowledge at one particular time and/or place was used to develop the same kind of knowledge at another time and/or place (Hassenteufel, 2005, p. 126). Analyzing transferences aims to prioritize the reasons and ways in which a knowledge develops, and to what degree of intensity. Hassenteufel also draws particular attention to the sociology of the actors who perform these transfers, their modes of receiving elements and how they are 'translated', as well as the way in which this knowledge mixes transferred elements with those already in existence (hybridization). Hassenteufel explains that "the sociology of actors who operate transferences, and who are often transnational actors (experts from international organizations, senior international officials, consultants, etc.) is indeed necessary to understand how the models of public action are widespread3" (Hassenteufel, 2005, p. 126). These transnational actors are important producers of reports:

\footnotetext{
These reports have a logical form (a beginning, middle, and an end) and are broken down into temporary sequences that are causally linked so that they are more easily understood. Reports depart from the present to describe one or more likely scenarios depending on the decisions that should be taken ${ }^{4}$. (Hassenteufel, 2005, p. 127).
}

These international actors give lengthy discourse and laborious action on journalism: we can see this in the World Association of Newspapers and News Publishers - WAN-IFRA (see the analysis by Langonné and Prodhomme, 2014) or in international Anglophone organizations like the Pew Research Centre Project for Excellence in Journalism (Pereira \& Le Cam, 2018), not to mention other international organizations like the International Federation 
of Journalists (IFJ) and the discourses it has produced in its world or regional congresses. This perspective thus becomes a field of study of globalization (Kott, 2011) from a certain concept of journalism. The analysis of international circulations can address the representations of journalism, the way in which certain practices have been developed (in relation to technique, the development of certain journalistic genres, etc.), the processes that allow such models to become references (the great figures of international journalism, the development of certain management models or certain material forms of work organization), as well as the ways of doing investigative journalism, literary journalism, television journalism, among others.

\section{b) Studying identities and compositions of professional}

groups. Studies on professional sociology compare the processes of professionalization, the historical construction of the legal status of journalists, the political influences on these definitions, the diversity of actors outside the professional group, and the reasons for this diversity. An approach was conducted by Le Cam and Ruellan (2004) to try to draw the specific and comparable features of the processes of professionalism, professionalization, and the constitution of a "profession" of journalists in Brazil, France and Quebec. This article - as indicated in the title - sought to rediscover the universal side of journalism as a professional group, and particularly to discuss whether this side even existed. The research attempted to open up the comparative approach to include other research problems beyond studies of professional values and their implications on the practice. Works on European journalists (Baisnée, 2003; Bastin, 2003), on journalism in France and Italy (Saïtta, 2006) or Brazil and Portugal (Novais et al., 2013) already exist. These works could be furthered or refined through more in-depth comparative analyses of careers and ways to represent, to think about, to feel and to live journalism. Florian Tixier (2019) used this approach in his analysis of European news producers. In addition, we adopted a particular and slightly different approach for a study we have been conducting over the last few months, comparing the history of case law used for granting press passes / professional registry of journalists between the countries of Belgium and Brazil. Despite the differences between the two countries in terms of the history of the journalist recognition process, this particular study focuses on case law and all the routine decisions that were made, whether by the courts (in Brazil) or by 
a commission of journalists and media entrepreneurs (in Belgium). Over time the rules for obtaining journalist credentials in both these countries have adapted to the shifting work environment and the way journalism is performed. Yet another study, initiated by Paula Melani Rocha and Dione Moura, aims to compare the place of women journalists in work environments in France, Belgium and Brazil (Rocha et al., 2018). In this study, despite the visible similarities in terms of the vertical and horizontal segregation of women, there are whole areas yet to be observed in terms of the feminization of the profession or how to better understand men and women's place in journalism, from internships to the individual development of careers.

\section{c) Studying work practices and conditions in media}

companies. Analyzing job insecurity, the ways young journalists enter and socialize in the profession, the organizational, management and socioeconomic strategies of media companies, the public's role in organizational decisions, relations with sources, with the public and with peers, the integration of new publishing tools, the use of social networks, and using audience data in marketing strategies are some of the areas that could benefit from a comparative analysis in two or more countries. In this regard, Arraes et al. (from this edition) use a comparative approach to observe how relations between the newsrooms and marketing departments in two different media organizations are established; one in Brazil and the other in Belgium. Paulino and Oliveira used a similar approach for a comparative study on the role of ombudsmen in Brazil and Portugal (Paulino \& Oliveira, 2014).

In order to do this it is necessary to define what must be observed (the relations or roles that refer to specific cultural modalities?), and try not to confuse practices that use a similar approach but refer to very different realities. This challenge was a point of interest in a comparative study on the identity of online journalists (Le Cam \& Pereira, forthcoming). For example, Brazilian respondents, when narrating their professional backgrounds, did not see any difference between working in the media sector from working in public or organizational communication. This can be explained by the status that comes with the position of press secretary, one which journalists found very attractive in the 1980s (also supported by academic and labor unions) which, over time, the Brazilian professional community has recognized as journalistic work. However, the situation is completely different in France or Belgium where, even if mobility between the 
journalism and communication sectors is similar, an alarmist discourse is prevalent on the changing professional status and job insecurity (journalists must work in the area of communication in order to make a living) which in turn leads to a professional discourse on the need to differentiate between the practices of journalists and communicators. So, comparing the practices and ways of understanding a journalist's daily work is a way to focus on a specific aspect, to better see the differences and similarities in a real context, avoiding the constant stereotypes associated with disseminating the western model of journalism (Mc Mane, 1992).

d) Studying content. Make comparisons of the forms for processing the same information and how that information is circulated, and studying specific genres, different titles, illustrations and caricatures all help towards understanding the national brands and local media representations broadcast by media. Understanding how fake news is produced and the tools used to do so, and understanding the forms of propagation and how the public uses them are also possible avenues that could be explored in works between France, Belgium and Brazil. There are few examples comparing this content. Lisboa and Aguiar (2017) conducted an analysis of news agency dispatches between Brazil and Lusophone Africa. This kind of analysis was also used in works on the coverage of Brazilian news in foreign newspapers, such as Colzio (2017), who analyzed the modalities of agenda-setting in President Lula's second term for the newspaper EI Pais. This research line was also used by researchers working on very specific themes such as the mediatization of violence between France and Brazil (Macé \& Peralva, 2005), or on representations of the right or left political parties in a comparison of the Brazilian and French press during the 2002 Brazilian presidential elections and the 2007 French presidential elections (Ribeiro, 2015). Lastly, relatively broad sample of comparisons could be made within the framework of a research program, such as a study on the reciprocal images of Brazil and France (Parvaux, 2019). These research programs and projects could be enriched from journalism studies that move away from simply comparing media coverage and focus more on the production of social media content or on the production, circulation and falsification of fake news by journalists.

One last possible research avenue could be to compare the metadiscourse in journalism (Oliveira, 2016). Compare what 
journalists say about themselves and the discourse they create about the profession, but also what others say about journalism. For example, the discourse of politicians has criticized journalists and the media for a long time; and the discourse of scientists on media practices and communication professionals. Taking an interest in the discourses on opinions and criticisms about journalism, both present and past, made by a variety of actors would provide more information on the resources used by critical discourse on journalism and its national - and transnational - particularities.

\section{Theoretical framework and methodological choices}

All of these research avenues are based on one fundamental principle: to avoid the juxtaposition of studies conducted on similar objects, and this way, hope that cross-country studies will be significant. We need to find, or even devise, methodologies that allow national diversities (social, linguistic and cultural) to emerge simultaneously in order to better understand transnational approaches.

Returning to texts on comparative analysis methodologies is one approach that reinforces a central idea, according to the principles of Glaser and Strauss:

(...) comparative analysis can, like those other methods, be used for social units of any size. Some sociologists and anthropologists customarily use the term comparative analysis to refer only to comparisons between largescale social units, particularly organizations, nations, institutions, and large regions of the world. But such a reference restricts a general method to use with one specific class of social units to which it has frequently been applied. Our discussion of comparative analysis as a strategic method for generating theory assigns the method its fullest generality for use on social units of any size, large or small, ranging from men or their roles to nations or world regions. Our own recent experience has demonstrated the usefulness of this method for small organizational units, such as wards in hospitals or classes in a school $^{5}$. (Glaser \& Strauss, 2017, pp. 21-22).

So, if comparison is a fundamental perspective for understanding social reality, and in the specific case of journalism studies, understanding professional identities, practices, or even media environments, what kind of approaches might one adopt to do so?

The initial approach would be to select the object of comparison. The first selection is the case study approach. The works of Hirschl (2005) in Comparative Law are particularly relevant 
here. It is really a matter of carrying out an in-depth examination and confrontation of different cases, integrating them with historical, political, economic and social insights. There are four principles which are applied in this case: the "most similar cases" principle that allows one to focus on very similar characteristics that reveal the environment, the research object itself or a specific situation. Thus, a comparative study on the modalities of information production during the World Cup in Brazil among Brazilian, French and Belgian journalists could allow us to observe a practice where the research object (the World Cup) was the same for all journalists which, in turn, may lead to revealing interesting cultural differences through sports coverage. The second principle is the opposite of this, and involves selecting the "most different cases". One example is a comparison that would look at how journalists enhance and learn about the area they are covering in poor neighborhoods of large cities. Comparing this practice and the journalists' anticipation would lead to quite contrasting results between the three countries. The third principle refers to "prototypical cases" which is a kind of shortcut to speed up the understanding of a concept or a theoretical perspective. In this regard, Brazilian, French and Belgian political journalists could be the basis for analyzing competing relations established between media and political actors, even considering the very different national, political and journalistic configurations. Lastly, the "most difficult cases" principle aims to select countries with very different configurations in order to test a hypothesis which is fundamental to the research. An example of this could be to propose an analysis of non-white journalists in the three countries where the issue of diversity in journalism is either a relatively taboo subject (Belgium), an issue discussed but rarely addressed (France), or a clear fact that gets little attention $\left(\mathrm{Brazil}^{6}\right)$. In this sense, this perspective is similar to the one that isolates the variables which are to be compared, where researchers work in their respective countries on similar topics and find variables which are quite different from what they are studying themselves. It would be advantageous if there were more distinct cases or contradictory examples to select so as to allow for testing hypotheses or intuitions (Becker, 2002, p. 319).

A second approach which could be used to present this kind of research is writing national reports (Vigour, 2005; Gueranger, 2012) on a particular case. For comparison purposes, each researcher gathers, from a text, a set of data relating to a case and highlights 
the main features, the evolution of any possible historical, economic, and political connections, and the particularity of the case itself. For example, two reports could be written in two or even three media outlets in France, Belgium and Brazil in order to ascertain the basic elements for comparison. Researchers are then responsible for completing these reports by conducting qualitative interviews, observation periods, or analyzing texts (professional or media). In addition, a historical approach could be developed to compare the history of journalism or media among the three countries.

The third approach is group research, a group of two researchers (or more) from different nationalities and who work together on a particular research problem and conduct field research in their individual countries, but use the same theoretical framework and methodological protocol, from which they can establish a comprehensive debate over the course of the research project. The first stage of a study on the identity of online journalists in Brazil and France (2010-2014) involved 20 semi-structured interviews conducted with journalists, 10 from each country (Le Cam \& Pereira, 2015). The objective was to select a variety of journalist profiles of similar age, gender, status, and employment conditions. A simple script was used so each researcher could conduct these interviews according to the individual context of each country. Of course the research problem had been decided on collectively based on common intuition and Francophone, Lusophone, and Anglophone bibliographic references. A series of exchanges about the Francophone and Brazilian media contexts was then performed. Data analysis was carried out individually in each country first, and then performed collectively, with the aim of understanding the different modalities of being and thinking as an online journalist in France and Brazil. This gave us our first comparative results on the representation of journalistic careers in the two countries, it gave us an analysis of the relationship these journalists have with their sources and with the public.

This phase allowed us to reveal transnational processes, to show similarities and differences between the narratives, trajectories and professional practices of Brazilian and French journalists.

The work's main contribution is pair work. When used for intercultural comparative research, pair work provides for a real immersive and intersecting approach. This is what we are currently doing with doctoral students from the Brussels Free University and the University of Brasilia. The goal is to offer students the opportunity to 
immerse themselves in the history of colleague's country, to observe the evolution of journalism and learn about that country's cultural, political and economic history, to learn the language and to better understand one another's environment. Conducting research in pairs and groups is one way to try and avoid, over time, obstacles that have appeared in earlier comparison approaches:

- When each one works in their own country and finds national explanations for comparison;

- When finding national data on pre-defined criteria without any in-depth knowledge of the other's context;

- When there is no procedure for distancing ourselves from internalizing the conventions and culture of our own country;

- When one does not understand the language of the other and, as a result, all the misunderstandings and misconceptions that can bring.

Pair work can be further reinforced by carrying out collective work in the field of research: conducting joint research, interviewing in twos, and writing together and becoming more proficient in each other's language. Part of this process draws on principles defined by the Rapid Ethnography (RE) perspective (Le Cam \& Pereira, $2017 \mathrm{~b}$ ). This method is a combination of methodologies (interviews, participant observation, document research, surveys and focus groups) from diverse research fields, carried out by teams of local and foreign researchers (Halme et al., 2016). In the case of RE, conducting research collectively is a way for increasing the time or resources needed to conduct a long-term ethnography (Kluwin et al., 2004). The conditions of this approach can be quite productive. Both researchers are presented with the respondent's report, and that report has not been written or the interview was not conducted by anyone else prior. The interview is an opportunity for the two researchers to exchange their national and cultural viewpoints in all stages of the research. It provides a direct interrogation, in situ, using questions from a national and cultural perspective. But, above all, it enables the researchers to work together to generate and interpret the data. This is a way of giving or taking the time needed to better understand the foreignness of the other or to help perceive situations in which the difference may not be so apparent. Having an intercultural group conduct a research project helps change the national view of the research object. In 
doing so, this approach not only answers a transnational challenge, but also constantly adjusts the knowledge of the research object and its problematization throughout the research and intercultural perspectives. The researchers see this perspective as an original and fruitful alternative to other comparison projects, one that seeks to preserve the richness of national realities and the accurateness of the elements to be compared, thereby justifying an inductive and qualitative methodology. Of course, a number of pragmatic conditions must be met. On one hand, both researchers should have a general understanding of the language used in the interview in order to make it easier to understand what is being said. On the other hand, one needs to find sources to finance this type of project, one which may allow for frequent travelling and accommodation.

\section{Conclusion: the political and scientific importance}

Comparing, decentralizing, bringing in other viewpoints, working on our own conventions and on our blind spots in fields of research can benefit from other viewpoints. Comparing allows us to see, through the eyes of others, similarities, differences, and the unexpected. Building intercultural groups for comparative research is a temporal, relational, scientific, and political commitment. This commitment forces the researcher to perform an activity that could have an effect on the social world, both on the world of the observed actors (Broqua, 2009), and on the scientific world itself.

And, at a time when research in social sciences, especially media and journalism, may face political and economic barriers in some countries (such as budget cuts) it is more important than ever to build cross-cultural, transnational ties that allow researchers to move back and forth, that create collective projects, and that compare different situations and similar problems. Intercultural research creates friendships, bonds and, above all, forms of mutual solidarity; interknowledge that is the foundation for and transforms the often closedoff viewpoints we have of ourselves, our research and our perspectives. Comparison, as it is thought of here, is a human and intellectual adventure; it is a political and scientific gesture of goodwill.

It should deal with three forms of constraints that reveal the dynamics of the researcher's commitment and the room for maneuver he may have. 
On one hand, building cross-cultural projects of comparison is a way of finding out what kinds of research funding are available. Lelubre states that a sociologist

\begin{abstract}
should be vital to acquiring legitimacy and denouncing all forms of symbolic violence (Mauger, 1995), our relationship with public authorities could be an obstacle to all scientific work. If science is seen as a force of opposition (Marchat, 2001), it can be independent of the state. However, funds coming from public authorities are indispensable to numerous research centers, universities and researchers, regardless of their initial position$^{7}$. (Lelubre, 2013, p. 17).
\end{abstract}

However, this opposition could be expanded to modify relations and help build public policies with the actors who fund the research. This is an avenue which has been previously explored by Fábio Pereira, who has been building a relationship with the Belgian and French embassies. He has also suggested creating a collective fund for financing research projects between the Federal District in Brazil and Wallonie-Bruxelles-International (WBI).

The selection of themes and the challenges those themes may present form another dynamic. Some political studies focusing on gender or even the history of certain time periods may be delayed or excluded for ideological reasons. In doing so, researchers come to the understanding that "conducting research means their individual and community concerns become part of the political agenda8" (Anadon, 2013, p. 5).

\begin{abstract}
Can we be clearer about the need to replace scientific and methodological debates within the political dynamics that they reshape and which they, in turn, structure? From this perspective, the North American experience in recent years has shown that methodological orientations are heavily dependent on research funding policies, as they favor hypotheticaldeductive approaches and wide comparisons, threatening the survival of qualitative methods (Becker, 2009) ${ }^{9}$ (Gueranger, 2012 , on-line).
\end{abstract}

In cases like these, international solidarity is important to be able to discover research problems in certain contexts that might otherwise remain hidden. This is why building transnational research networks, organizing international events centered on tackling challenges (either from a social reality point of view or in terms of main themes or questioning the methodological choices), and defending newspapers which are not nationwide, but are released at different national or regional levels can all be productive strategies. 
Lastly, the academic, political and professional education of doctoral students is another fundamental element for encouraging the promotion of comparative research. This approach, as we previously mentioned, forces us to explain, and therefore deconstruct, our a prioris in order to question ourselves. At this stage of sharing research, all questions are important towards building our professional identities. Working in pairs also provides a better understanding of the national scientific environments and of the various modalities of building a scientific career, but also of how to build international projects, to work together to search for funding, and to overcome any difficulties that may occur in communication or understanding. And all these actions contribute to placing the doctoral student in an environment conducive to solidarity, one that is distanced from hyper-competition so that said researcher is able to build an international network in publication or multilingual communication. At a time when entry into the academic labor market is competitive and full of numerous injunctions (both in terms of publications and research networks) (Frances, 2012), working in pairs or small international groups over long periods of time, with common research objects, provides another way to think about comparative research; a more grounded, in-depth way that could be part of major international congresses from time to time; or one that also considers the comparative perspective to be like a springboard towards a career.

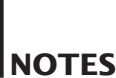

1 This text is the result of exchanges we have had with Fábio Pereira since 2013, and is the beginning of a research project comparing professional identities of online journalists in Brazil, France and Belgium. It was also largely inspired by a course we shared in the second semester of 2017 at the University of Brasilia on international comparison in journalism studies, and a reflection we made on interview techniques for pairs of international researchers. This text is an individual production, but it is also produced in dialogue form, in terms of our exchanges. At the same time, I take full responsibility for all opinions expressed herein.

2 See: https://www.worldsofjournalism.org/: "Based on a landmark study that has collected data from more than 27,500 journalists in 67 countries, Worlds of Journalism offers a groundbreaking analysis of the different ways journalists perceive their duties, 
their relationship to society and government, and the nature and meaning of their work".

3 Original: "La sociologie des acteurs opérant des transferts, qui sont souvent des acteurs transnationaux (experts auprès d'institutions internationales, hauts fonctionnaires internationaux, consultants, etc.), apparaît en effet nécessaire pour comprendre comment sont diffusés des modèles d'action publique".

4 Original: "Ces récits ont une forme logique (avec un début, un milieu et une fin) et sont découpés en séquences temporelles qui s'enchaînent de manière causale, afin de les rendre aisément compréhensibles. Les récits partent du présent pour décrire un ou plusieurs scénarios probables en fonction des décisions qui devraient être prises".

5 "(...) comparative analysis can, like those other methods, be used for social units of any size. Some sociologists and anthropologists customarily use the term comparative analysis to refer only to comparisons between largescale social units, particularly organizations, nations, institutions, and large regions of the world. But such a reference restricts a general method to use with one specific class of social units to which it has frequently been applied. Our discussion of comparative analysis as a strategic method for generating theory assigns the method its fullest generality for use on social units of any size, large or small, ranging from men or their roles to nations or world regions. Our own recent experience has demonstrated the usefulness of this method for small organizational units, such as wards in hospitals or classes in a school".

6 Dione Oliveira Moura currently conducts research on black women and their place in journalism; she is one of the first to be interested in the subject.

7 Original: "se doit d'être critique pour acquérir légitimité et dénoncer toute forme de violence symbolique (Mauger, 1995), notre rapport aux autorités publiques pourrait constituer un obstacle complexifiant tout travail scientifique. Si la science se veut un contre-pouvoir (Marchat, 2001), elle doit pouvoir être indépendante de l'État. Or, les fonds émanant des pouvoirs publics se font indispensables pour de nombreux centres de recherche, universités et chercheurs, quel que soit leur positionnement initial".

8 Original: “l'exercice de la recherche en plaçant leurs préoccupations 
individuelles et communautaires dans l'agenda politique".

9 Original: "Peut-on dire plus clairement la nécessité de replacer les débats scientifiques et méthodologiques au sein d'enjeux politiques qui les structurent et qu'ils structurent en retour ? Dans cette perspective, l'expérience américaine des dernières années montre que les orientations de méthode sont aujourd'hui intimement dépendantes des politiques de financement de la recherche qui, parce qu'elles privilégient les démarches hypothético-déductives et la réalisation de vastes comparaisons, menacent la survie des méthodes qualitatives (Becker, 2009)".

\section{REFERENCES}

Adghirni, Z. L., \& Pereira, F. H. (2011). A experiência da rede de estudos sobre o jornalismo (REJ). Brazilian Journalism Research, 7(2), 25-42. https://doi.org/10.25200/BJR.v7n2.2011.335

Anadón, M. (2013). La recherche sociale et l'engagement du chercheur qualitatif: défis du présent. Recherches qualitatives, Hors-série, 14, 5-14. Retrieved from http://www.recherche-qualitative.qc.ca/ documents/files/revue/hors_serie/hs-14/RQ-HS-14-Anadon.pdf

Anciaux, A., Herrmann, J. D., \& Guazina, L. (2017). Études comparatives sur le journalisme, les médias et la politique. Sur le journalisme, About journalism, Sobre jornalismo, 6(2), 4-11. Retrieved from https://surlejournalisme.com/rev/index.php/slj/article/view/313

Baisnée, O. (2003). Un impossible journalisme européen. Hermès, La Revue, 35(1), 145-151. Retrieved from https://www.cairn.info/revuehermes-la-revue-2003-1-page-145.htm

Bastin, G. (2003). L'Europe saisie par l'information (19522001): des professionnels du journalisme engagé aux content coordinators. Cahiers Politiques, 19-41.

Becker, H. S. (2002). Les ficelles du métier: comment conduire sa recherche en sciences sociales. La découverte.

Broqua, C. (2009). L'ethnographie comme engagement : enquêter en terrain militant. Genèses, 75(2), 109-124. https://doi.org/10.3917/ gen.075.0109

Broustau, N., Jeanne-Perrier, V., Le Cam, F., \& Pereira, F. H. (2011). L'entretien de recherche avec des journalistes Propos introductifs. Sur le journalisme-about journalism-sobre jornalismo, 1(1), 6-12. Retrieved from https://surlejournalisme.com/rev/index.php/slj/article/view/16 
Frisque, C. (2016). Les SIC dans les recherches sur le journalisme au sein d'un laboratoire pluridisciplinaire, issu de la science politique. Revue française des sciences de l'information et de la communication, (9). https://doi.org/10.4000/rfsic. 2457

Frances, J. (2012). Portrait du doctorant en entrepreneur. Mouvements, 71(3), 54-65. https://doi.org/10.3917/mouv.071.0054

Glaser, B. G., \& Strauss, A. L. (2017). Discovery of grounded theory: Strategies for qualitative research. Routledge.

Golzio, D. G. (2017). Brazil in Spain: Agenda-setting in the Newspaper El País during President Lula da Silva's Second Government Term. Brazilian Journalism Research, 13(3), 146-161. https://doi. org/10.25200/BJR.v13n3.2017.998

Gueranger, D. (2012). La monographie n'est pas une comparaison comme les autres. Terrains travaux, 21(2), 23-36. Retrieved from https://www.cairn.info/revue-terrains-et-travaux-2012-2-page-23.htm

Hanitzsch, T. (2009). Comparative journalism studies. In K., WahlJorgensen \& T., Hanitzsch (Eds.), The handbook of journalism studies, (pp. 413-427). Routledge.

Hanitzsch, T., Hanusch, F., Ramaprasad, J., \& de Beer, A. S. (Eds.). (2019). Worlds of journalism: Journalistic cultures around the globe. Columbia University Press.

Hassenteufel, P. (2005). De la comparaison internationale à la comparaison transnationale. Revue française de science politique, vol. 55(1), 113-132. doi:10.3917/rfsp.551.0113

Hirschl, R. (2005). The question of case selection in comparative constitutional law. The American Journal of Comparative Law, 53(1), 125-156.

Kluwin, T. N.; Morris, C. S., \& Clifford, J. (2004). A Rapid Ethnography of Itinerant Teachers of the Deaf. American Annals of the Deaf, vol. 149 no. 1, 62-72. https://doi.org/10.1353/aad.2004.0012

Kott, S. (2011). Les organisations internationales, terrains d'étude de la globalisation. Jalons pour une approche socio-historique. Critique internationale, 52(3), 9-16. https://doi.org/10.3917/crii.052.0009

Langonné, J., \& Prodhomme, M. (2014). The WAN-IFRA discourse: advice, application, and disqualification of organisational models in media. Brazilian journalism research, 10(1), 24-39. https://doi. org/10.25200/BJR.v10n1.2014.624

Le Cam, F. \& Pereira, F. H. (In Press). Un journalisme en ligne mondialisé; Socio-histoire comparative/ Um jornalista on-line mundializado: Socio-historia comparativa. 
Le Cam, F. \& Pereira, F. H. (2017a). A comparação da identidade dos jornalistas online em suas relações com os públicos no Brasil e na França. Observatorio (Obs*), 11 (1), 60-82. https://doi.org/10.15847/ obsOBS 1102017868

Le Cam, F., \& Pereira, F. H. (2017b). Enjeux de l'entretien interculturel de recherche en études du journalisme, communication présentée lors du séminaire interne Arènes, Rennes.

Le Cam, F., \& Pereira, F. (2016). Interroger les normes des chercheurs en journalisme. Introduction. Sur le journalisme, About journalism, Sobre jornalismo, 5(2), 16-20. Retrieved from https:// surlejournalisme.com/rev/index.php/slj/article/view/263

Le Cam, F., \& Pereira, F. H. (2015). Understanding journalists? paths: a study of biographic narratives from web journalists. Transnational Words of Power Journal, 1(1), 158-176.

Le Cam, F., \& Ruellan, D. (2004). Professionnalisme, professionnalisation et profession de journaliste au Brésil, en France et au Québec: un essai de comparaison. In J.-B., Legavre (Ed.), La presse écrite: objets délaissés (pp. 53-69). Paris: L’Harmattan. (Logiques politiques).

Le Cam, F., \& Ruellan, D. (2014). Changements et permanences du journalisme. Paris: L'harmattan.

Lelubre, M. (2013). La posture du chercheur, un engagement individuel et sociétal. Recherches qualitatives, 15-28. Retrieved from http:// www.recherche-qualitative.qc.ca/documents/files/revue/hors_serie/ hs-14/RQ-HS-14-Lelubre.pdf

Lima, S. P., \& Mick, J. (2013). Sindicalização e identidade política dos jornalistas brasileiros. Estudos em Jornalismo e Mídia, 10(1), 4-24.

Lisboa, J. C., \& Aguiar, P. (2017). News Circulation in the PortugueseSpeaking Space: News Exchange between News Agencies of Brazil and Lusophone Africa. Brazilian Journalism Research, 13(3), 12. https://doi.org/10.25200/BJR.v13n3.2017.1011

Macé, E., \& Peralva, A. (2005). Jacobinisme vs. industrie culturelle médiatisation de la violence en France et au Brésil. Cultures \& conflits, 59(3), 47-85. Retrieved from https://www.cairn.info/revue-cultureset-conflits-2005-3-page-47.htm

Mc Mane, A. A. (1992). Vers un profil du journalisme. Reseaux, (51(1), 67-74. Retrieved from https://www.cairn.info/revue-reseaux1-19921-page-67.htm

Mejor (2013). Atas do II Colóquio Internacional Mudanças Estruturais do Jornalismo. Retrieved from https://surlejournalisme.com/wpcontent/uploads/2014/01/Atas_Mejor_FINAL1.pdf 
Mejor (2015). Anais do III Colóquio Internacional Mudanças Estruturais do Jornalismo. Retrieved from http://mejor2015.sites.ufsc.br/wpcontent/uploads/2015/05/merged-51.pdf

Mendras, H. (1995). Éléments de sociologie. Paris: Armand Colin.

Moura, D. O., Pereira, F. H., \& Adghirni, Z. L. (Eds.). (2015). Mudanças e permanências do jornalismo. Florianópolis: Insular.

Moura, D. O., Rocha, P. M., Damian-Galliard, B, \& Le Cam, F. (2018). Gender intersectionality and horizontal and vertical concentration of women journalists in Brazil, France and Belgic Francophone's journalism. An introduction to the problem. In lst Brazil-France-Francophone Belgium Journalism Research Conference: The Sociocultural Frontiers of Journalism in Brazil and in Francophone space. São Paulo: 12-13, November 2018. Retrieved from http://sbpjor.org.br/congresso/ index.php/BFFB/BFFB2018/paper/view/1053

Novais, R. A., Moreira, S. V., \& Silva, L. (2013). Companheiros de armas? Uma comparação dos mundos jornalísticos português e brasileiro. Brazilian Journalism Research, 9(1), 76-97. https://doi. org/10.25200/BJR.v9n1.2013.501

Oliveira, M. (2016). Metajornalismo: do discurso normativo à autorreferencialidade como condição ética. Sur le journalisme, About journalism, Sobre jornalismo, 5(2), 32-43. Retrieved from https:// surlejournalisme.com/rev/index.php/slj/article/view/254

Örnebring, H. (2012). Comparative Journalism Research - An Overview. Sociology Compass, 6/10, p.769-780 https://doi. org/10.1111/j.1751-9020.2012.00493.x

Parvaux, S. (2019). Images Réciproques du Brésil et de la France: actes du colloque organisé dans le cadre du projet France-Brésil. Éditions de l'IHEAL.

Paulino, F. O., \& Oliveira, M. (2014). Ombudsman em veículos de comunicação do Brasil e de Portugal: reflexão sobre atividades desenvolvidas entre 1989-2013. Brazilian Journalism Research, 10(1), 64-81. https://doi.org/10.25200/BJR.v10n1.2014.585

Pereira, F. H. F., \& Le Cam, F. (2018). A retórica das mudanças: a circulação internacional de discursos sobre o jornalismo on-line. In J. Colussi, F. Gomes-Franco e Silva, \& P. Melani Rocha (Eds.), Periodismo ubicuo: convergencia e innovacion en las nuevas redacciones ( $p$ p. 111-134). Bogota: Editorial Universidad del Rosario.

Pinson, G. (2016). La culture médiatique francophone en Europe et en Amérique du Nord. Saint Fois: Presses de I'Université Laval.

Ribeiro, M. P. (2015). "Droite» et «gauche» dans les discours d'un événement électoral. Une étude sémantique et contrastive des presses 
brésilienne et française: les élections présidentielles de 2002 au Brésil et de 2007 en France (doctoral dissertation), Sorbonne Paris Cité.

Saitta, E. (2006). Les transformations du journalisme politique depuis les années 1980: une comparaison France/litalie (doctoral dissertation). Université de Rennes 1 / Libera università di lingue e comunicazione IULM, Itália.

Sobrinho, A. P. R. (2018). Brazilian Journalism in the 19th Century: A History of the French Influence and of the Beginning of JournalisticLiterary Relations. In lst Brazil-France-Francophone Belgium Journalism Research Conference: The Sociocultural Frontiers of Journalism in Brazil and in Francophone space. São Paulo, novembro de 2018 . Retrieved from http://sbpjor.org.br/congresso/index.php/ BFFB/BFFB2018/paper/view/1033

Tixier, F. (2019). Incarner l'Europe par et dans les médias. Les militants d'information européenne et la construction d'un monde transnational du journalisme européen (doctoral dissertation). Université libre de Bruxelles.

Vigour, C. (2005), La comparaison dans les sciences sociales. Pratiques et méthodes, Paris, Édition La Découverte, collection Repères.

FLORENCE LE CAM. Journalism professor at the Free University of Brussels (ULB). Co-responsible for the Laboratory of Journalistic Practices and Identities (ReSIC-ULB, Belgium) and a researcher at Arènes (Rennes University, France), she conducts work on professional identities, the materiality of journalistic work and the socio-history of Belgian journalism. She has been conducting comparative research with Fábio Pereira on Brazilian, French and Belgian journalism since 2013. E-mail: flecam@ulb.ac.be 